\title{
臨床診断に苦慮した襄胞性リンパ管腫
}

\author{
立松慧親・大久保恒正・市原秀記・加藤幸弘
}

兵東踇・奥村康明

\section{A case of cystic lymphangioma defying diagnosis}

\author{
Norichika Tatematsu - Tsunemasa Oukubo - Hideki Ichinara \\ Yukihiro Katou - Iwao Hyodo • Yasuaki OKumura
}

\begin{abstract}
A case of cystic lymphangioma was recently encountered in which a buccal swelling had remitted on centesis and aspiration without any definitive diagnosis at the age of 2 years and recurred when the patient was 10 years old. Exploratory incision made under the clinical diagnosis of hemangioma disclosed the lesion to be cystic lymphangioma. Surgical treatment was performed by excision as extensively as feasible and the patient has been progressing favorably with no indications of recurrence five years. The case will be reported with a brief review of the literature.
\end{abstract}

Key words: cystic lymphangioma（孪胞性リンパ管腫）, buccal region（煩部）

緒

言

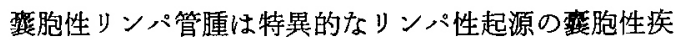
患であり，新生見，小昌期に頸部，顎下部に発生する比 較的まれな疾患である。

今回，われわれは 2 歳時に煩部が腫脹し穿刺，投薬な どの対症療法のみで，確定診断が得られないまま一時消

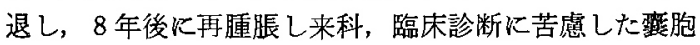
性リンパ管腫の 1 例を経験したので報告する.

症

例

患 者: 10踹 男見.

初 診: 昭和 59 年 4 月日日。

主 訴: 左側頖部より顎下部の厜脹.

家族歴・既往歴：特記すべき事項なし.

現病歴： 2 歳時, 母親が左側煩部の腫脹に気づき某総 合病院外科を受診. 煩部血腫の臨床診断下に 2 度の穿刺 をらけ，その都度血液様内容液を吸引したため，血管腫

岐阜大学口腔外科学教室

（主任：岡 伸光教授）

Department of Oral and Maxillofacial Surgery, Gifu University School of Medicine (Chief: Prof. Nobumitsu Oka)

受付日: 平成元年 9 月 28 日
が疑えれたが，確定診断が得られないまま自然消退し た.

今回，2 歳時と同様の症状で同科を受診し， 口赤十 字総合病院口腔外科沼介された.

現 症:

全身所見：喿養体格ともに良好で異常所見はみられな

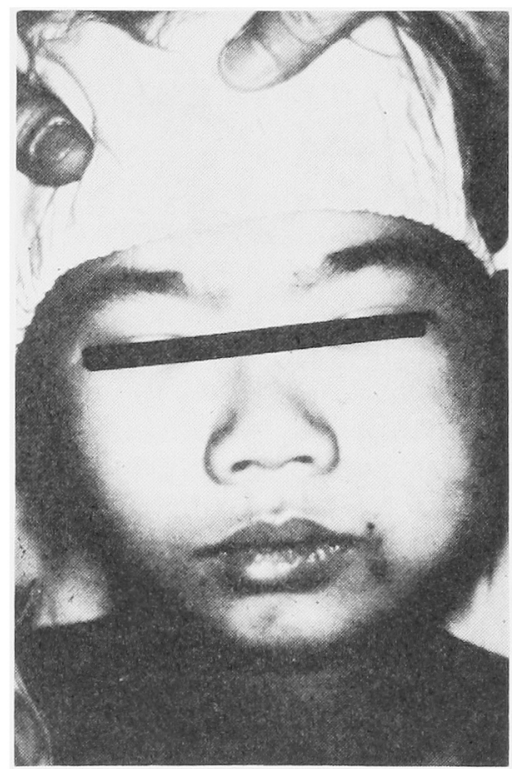

写真 1 顔貌写真 


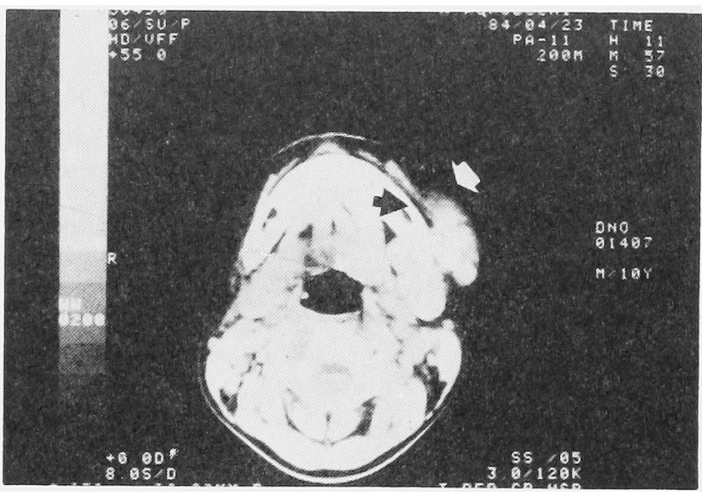

写真 2 CT 写真

矢印は境界不明瞭の尰瘤を示す

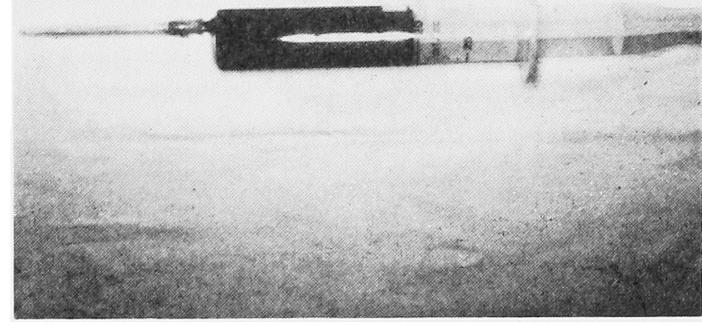

写真 3 内溶液を示す

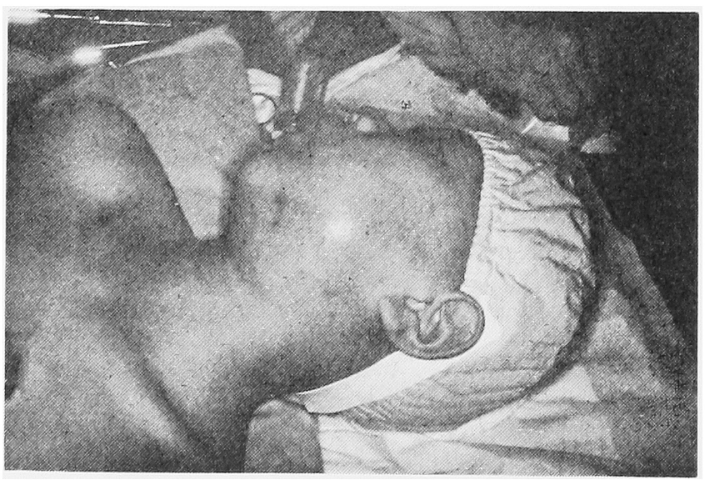

写真 4 手街特の煩部から顎下部の腫腿

かった．顔貌所見は左右非対称性で左側煩部に，び漫性 の腯脹を認め，触診により弾性軟で，波動を触知し，纴 痛を認めた（写真 1 ).

臨床検査成績：特に異常は認めなかった。

$\mathbf{X}$ 線所見：CT 所見により顂部から下顎部にかけて， 境界不明膫な腫瘤を諗めた（写真 2 ).

総頸動脈より $60 \%$ コンレイルよる CT 撮影では造影

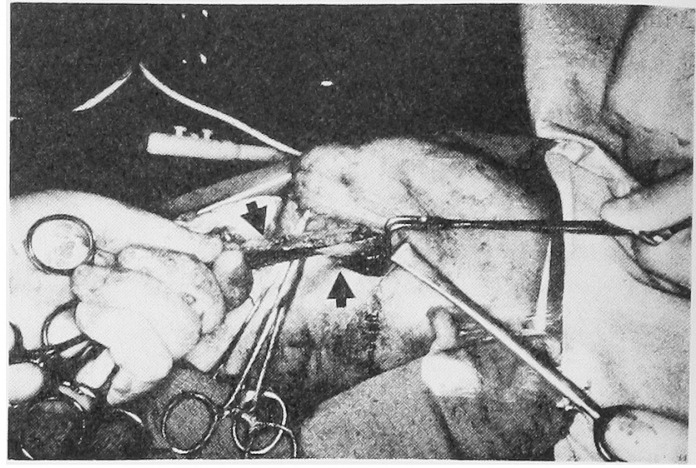

写真 5 術中写真, 矢印は覇胞壁の一部

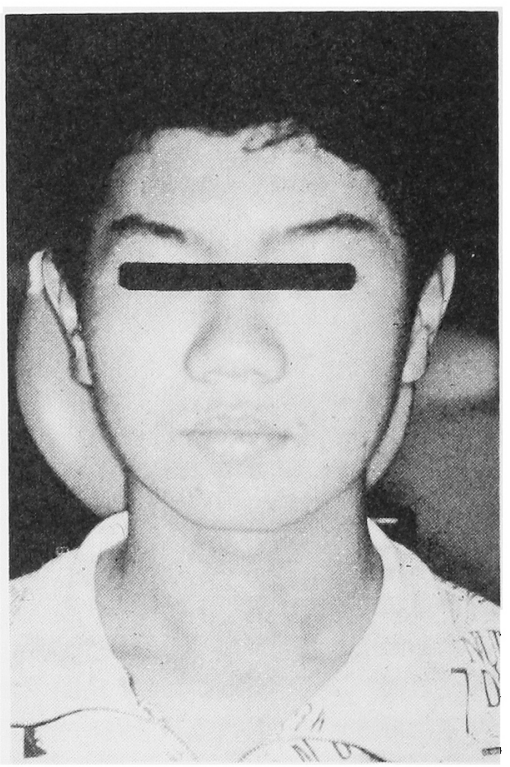

写真 65 年後の顔貌写真

効果は認められなかった。

臨床診断：煩部血管尰。

処置および経過：口膑内歯牙には異常所見なく，外煩 部よりの試験穿刺により血液様の色調を带びた内容液を 吸引（写真了），同処直により一時腫脹は縮小したが， 翌日には処䁂時より腫脹は增大し煩部から下㖽部，上頸 部までおよび，皮荿に発赤，光沢を有するいわゆる煩部 蜂窩織炎様症状となった。

昭和59年 4 月曰日，頓部腫脹は日増しに増大するた め, GOF 全身麻酔下に煩部血管腫の診断下に輸血を準 備し，試験切開を行った（写真 4 ）。左顎下部に $7 \mathrm{~cm}$ の切開を加え，広頸筋層を䟝離すると，暗黑赤色の薄い

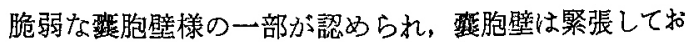

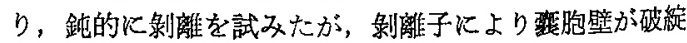
し, 約 $50 \mathrm{cc}$ の血液様内容液が流出した。手術所見より 


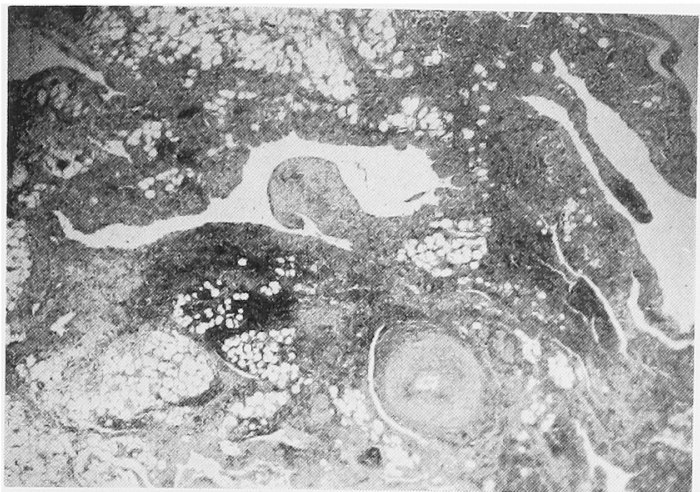

写真 7 病理組鐡写真 (H-E 染色 $\times 40)$

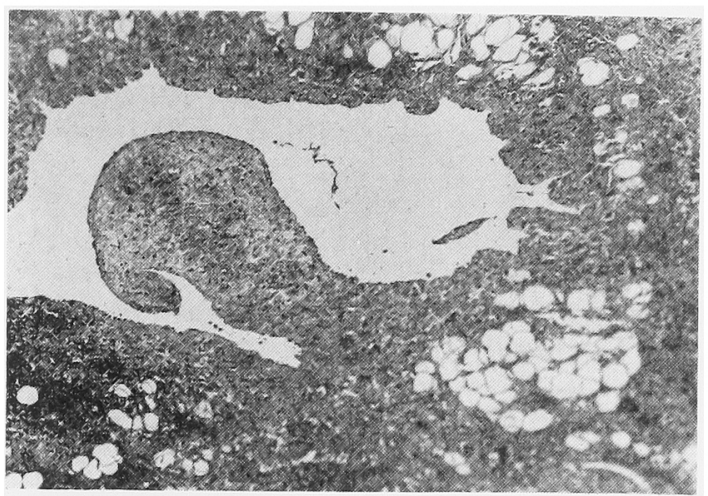

写真 8 病理組織写真 $(H-E$ 染色 $\times 400)$

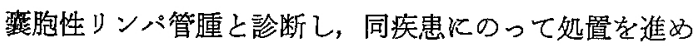
た。顀胞壁は一部周囲組織と癒着して括り，可及的に摘 出し得た（写真 5 ). 術後経過良好で 7 日後抜系し，泿 院した，術後 5 年の現在，顔貌は左右対称性で，手術時 の㾿痕を認めるのみで，顔面神経麻痺などの後遗症はな 々, 再発はない(写真 6$)$.

摘出物所見：内容液の流出により覇胞は緶小したが， 約 $100 \times 30 \times 30 \mathrm{~mm}$ の大きさで蹤胞壁は薄く脆弱で多胞 性であった。

病理組織学的所見：不規則に拡張した藮胞様空腺が脂 肪組織中に存在して括り，敖胞の内腔は細長く伸びた 1 層の内皮細胞で覆われて和り，1部にりン八球の集族も 散見できた（写真 $7 ， 8)$.

病理組織学的診断：嘿胞性リンパ管腫.

考察

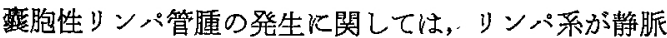
系から発生するか，問葉系組織から発生するか，異諭の あるところであるが，胎生 8 週ごろまでに5つの原始り ンパ藋として形成が始まり，これを基幹として各方面の
末梢部にりンパ采が形成されるこれらの原始リンパ罢 の遺残物として，これらの部位に一致して発生するもの である．5つの原始リンパ䣬とは，頸静脈に通ずる雨側

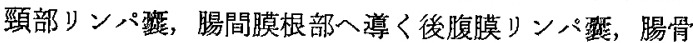
静脈に関係のある両側後部リンパ踛である ${ }^{12}$.

胎生初期の静脈内のリンパ組織は，合同して大きなり ンパ湿を形成し，これが静脈系開口しているが，後に この事は小さくなり，まっすぐ細くなる，この時にこ れらのリンパ系之静脈系との交通がなくなると、リンパ 系の和るな集合管化閉塞が起きて本症が発生すると述べ ている2).

リンパ管腫は，病理組織学的に分類すると単純性リン パ管腫，海綿状リンパ管腫，整胞状リンバ管腫の 3 型に 分類される ${ }^{3)}$. 日本小罗腫湯組織分類委員会ではさら に，全身性リンパ管腫症を追加している゙， 単純性リン パ管腫，海綿状りンパ管尰，霜胞状リンパ管腫はお互い 飞混合して腫瘤を形成することが多いとし，まれには血 管腫と一緒に混合して認められることがある゙．

発生部位注身体どの部位にも発生するが，頭頸部領域 では，池田ら゙は20症例中頸部に60〜70\%，腋简部に20

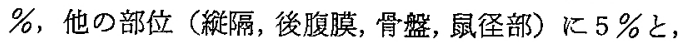
さらに本邦72症例ををと頸部に 40\%と，Ward $5^{5)}$

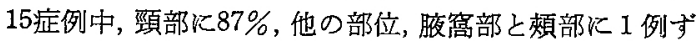
つの報告をして拉り，頸部が压倒的に多く，このことは 原始リンパ霆の両側の頸静脈部が胎生期の一番初めに発 生し，最も大きいためであるう，頓部に発生した報告で ( Ward $5^{(5)}$, 坂元 $5^{6)}$, 塩田ら たがって本症例での類部は比較的まれと思和れた。発生 時期については生下時または乳幼罗に発見されることが 多いとされ，活とんどが 2 歳末満までに発生する ${ }^{2)}$ 鵜 飼ら ${ }^{8)}$ は 8 例中 6 例湔述の時期に認めたと, その他の 2 例中 1 例飞39歳時をで, 全く無症状に経過したという

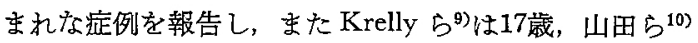
は18歳の報告を見る。

哣胞性リンパ管看の診断は, 発生部位, 臨床症状, 臨 床経過, 内容液の性状（一般には黄色を呈する透明漿液 性）から，比較的容易とされているが，本症例は頉部と そのまれな発生部位ととるに，既往歷より 2 藏時, 穿刺 にさいし常に血夜様内容液を吸引したことで，臨床的に 血管腫が疑われた，本症で頸部に発生した場合，踓胞内 飞感染が加わったり，出血が生でたりすると，急激な増 大をきたし生命の危険をきたすことがあると ${ }^{11)}$ ，さらに

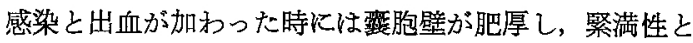
なり血管腫との鑑別が困難な場合があると報告されてい $ろ^{2}$. 本症例る入院後，急激に頼部が日增に增大したた め，臨床診断で血管腫とし，試験切開をせざるを得なか った．乙かし造影 CT 所見で造影効果がなかったこと， 内容液を放置しても凝固しなかったことなどから，やは り栗胞性リンパ管腫と臨床診断するのが妥当であったか 


\section{もしれない.}

また 2 歳時に突発的に頓部が腫脹し対症療法後, 数年 緩解していたが，今回同様な症状を呈した理由として は，血液様内容液を吸引したことから推測すると，なん らかの原因により嫼胞壁の太い血管が破綻したか，また は盾瘤が増大する過程のなかで腫瘤内に周囲血管を巻き 込み血管が破綻したのであろう。ささら今回入院し試験 穿刺後，急激に腫脹が増大した理由としては雚胞に隣接 した血管を損傷し䝮胞内に血液の眝溜を生じたのではな いかと思考される。

鑑別診断としては血管腫, 静脈瘤, 唾液腺貯留弉胞, 側頸霆胞, 皮様蓝胞, 脂肪腫らがあげられる。高橋 ${ }^{12)}$ 血管腫，側頸整胞，唾液腺の憼腫などとの鑑別が難しい ことがあると述べている。しかし定形的な翼胞性リンハ 管腫は診断にはさほど困難でないと思われる。

治療法としては，以前は種々な保存療法が行われてい， たが，今日では積極的に摘出手術が行われている。しか し，翼胞の性質上多胞性構造をもつそれぞれの部分が進 展することにより，特改的に進行し，筋肉，血管，神 経，および他の組織を巻き込むとされている。 したがっ てリンパ管腫を完全摘出するため，特に運動神経を切断 することより，いくらかとり残しがあっても良いとされ ている. 本症例も積極的に摘出をこころみ，可及的に摘 出した. 術後, 5 年を経過するが, 再発徵候なく経過良 好である。

\section{結語}

2 歳時に左側煩部に発生し, 穿刺吸引により一時消 退，その後10歳時に急激な腫脹の增大をきたした整胞性 リンパ管腫に対して口腔外より可及的に摘出を施行した ところ，術後経過良好で，5年後の現在，再発などの異 常所見は認めていない.
本論文の要旨の一部は第39回日本口腔科学会総会に拉 いて発表した。

\section{引用文 献}

1）池田惠一, 戸田智博, 他：小児のリンパ管腫. 外科治療 20(4)：374-387 1969 .

2) 草間 悟, 和田達雄, 他：外科 $\mathrm{MOOK}$ 㴿部腫 瘤の臨床。第 3 刷, 金原出版, 東京, 1982, 1529 頁.

3) 石川梧朗監修: 口腔病理学. 改訂版, 永末書店, 京都，1982，581-583頁。

4) 日本病理学会小児腫瘳組織分類委員会：小児軟 部組織腫湯の組織分類。日小外誌 11：529-544 1975.

5) Ward, P.H. and Angeles, L.: Surgical approach to cystic hygroma of the neck. Arch Otolaryng 91: 508-514 1970.

6）坂元晴彦，朝倉昭人，他：煩部に炎症を伴った 掏胞性リンパ管腫の 1 例。 日口外誌 27：4784821981.

7）塩田 猛, 吉田 広, 他: 頓部に発生した萣胞 性リンパ管腫の 1 例。 日口外誌 29：1489-1493 1983.

8）鵜飼幸太郎, 板倉康夫, 他: Cystic hygroma 8 症例の検討。耳番臨床 73: 679-685 1980.

9) Krelly, J. S., Carr, R.F., et al.. Cystic hygroma in a 17-year-old patient: report of case. J Oral Surg 36: 808-810 1978.

10) 山田隆一, 宮城帛俊雄, 他: cystic lymphangioma の 1 例. 日口外誌 26: 752-755 1980.

11）野村恭也, 本庄晸, 他：耳奥咽喉科。頭頸部 外科 MOOK, 顔面 - 頸部腫瘤。第 1 刷, 金原 出版, 東京, 1986, 118-121頁.

12) 高橋庥臣：先天性頸部腫脹。耳搌 55:847-856 1983. 